\title{
A Study on Multimodal Teaching Mode for Adult English Learners under Epidemic Situation
}

\author{
Ruihong Huang \\ Teaching Center, Zhejiang Open University, Hangzhou, China \\ Email: 870534247@qq.com
}

How to cite this paper: Huang, R. H. (2020). A Study on Multimodal Teaching Mode for Adult English Learners under Epidemic Situation. Open Journal of Modern Linguistics, 10, 366-374. https://doi.org/10.4236/ojml.2020.104021

Received: August 6, 2020

Accepted: August 22, 2020

Published: August 25, 2020

Copyright $\odot 2020$ by author(s) and Scientific Research Publishing Inc. This work is licensed under the Creative Commons Attribution International License (CC BY 4.0).

http://creativecommons.org/licenses/by/4.0/

\section{(c) (i) Open Access}

\begin{abstract}
The outbreak of the novel corona virus pneumonia in the world has a particularly extensive impact on the education system. Under the epidemic situation, adult English teaching should be combined with the characteristics of English education and the needs of adult learners. Based on multimodal discourse analysis theory, multimodal teaching mode for adult English learners uses multimodal learning platforms to guide teaching, carries out live broadcast teaching and organizes multimodal teaching activities at three levels including teaching preparation, teaching organization and teaching evaluation, so as to stimulate adult learners' interest in learning English, cultivate their autonomous learning ability, and effectively promote adult learners' knowledge construction and internalization.
\end{abstract}

\section{Keywords}

Multimodal Teaching Mode, Adult English Learners, Epidemic Situation

\section{Introduction}

The outbreak of the novel corona virus pneumonia in the world has caused great impact on the whole society. Epidemic prevention and control has a wide impact on the education system. How to suspend classes without stop learning is a great challenge. It is also a comprehensive topic involving teaching mode reform, teaching technology application and teaching quality assurance. Teachers at the front line of teaching should conform to the proposition of this era and take the epidemic as an opportunity to think about how to better carry out English education and improve the teaching effect.

Under the epidemic situation, adult English teaching should be combined 
with the characteristics of English education and the needs of adult learners to carry out and achieve better teaching effect. Teachers should be able to change the mode of thinking, further innovate teaching methods and forms, effectively play and use Internet information technology to provide targeted learning support for adult learners. Through exploring the multimodal teaching mode reform for adult English learners, this study can provide learners with multi-media and multi sensory information input, output channels and communication platform, which is more conducive to the development of adult English teaching. It can stimulate learners' interest in learning English, cultivate adult learners autonomous learning ability, and effectively promote adult learners' knowledge construction and internalization.

\section{Analysis of Multimodal Teaching Mode}

After Halliday put forward "language is a social symbol", scholars at home and abroad put forward multimodal discourse analysis theory, which rose in the 1990s. Kress, G. and Van Leeuwen, T. (Kress \& Van Leeuwen, 2001) analyzed multimodality. Tan, S. E., Marissa K. L. and O’Hallonran, K. L. (Tan et al., 2012) set up a multimodal research laboratory in Singapore. Although it is only more than 20 years, it combines theory with practice from the very beginning. At the same time of introducing the theory in China, various empirical studies are carried out. Multimodal discourse analysis theory regards language as a social symbol, and various symbols including language are regarded as independent and interactive symbol resources. While analyzing the linguistic features, it emphasizes the role of visual, auditory and behavioral semiotic modes such as images, colors, sounds and actions in discourse (Zhang, 2009). Scholars have studied the application of multimodal teaching theory in the classroom, so that the classroom is no longer limited to a single language teaching, but extended to a variety of modes, including pictures, PPT, music, network and so on.

The multimodal teaching mode based on multimodal discourse analysis theory combines multimodality with the existing teaching mode. The emergence of this teaching mode is the product of the continuous development and popularization of modern information technology and network technology and its application in English teaching. In this new mode of English teaching, the advantages of the network era can be brought into full play, and the interactive mode that adult learners are keen on can also be fully utilized. In the multimodal learning platform, various forms of multimodal teaching resources allow adult English learners to learn, interact and communicate in a multi-dimensional and all-round way. At the same time, teachers can also interact with adult learners through the multimodal platform. This interaction also facilitates teachers to optimize English teaching design according to the feedback, presentation and evaluation results of adult learners, so as to promote the positive development trend of English teaching effect. In the process of constantly enriching and improving English teaching resources and teaching design, English teachers have achieved 
self-improvement and development (Zhang, 2017), while adult learners have gained a better English learning environment and an all-round network interactive platform in the process of learning English. Instead of using a single medium or a single text, image, etc., adult learners can mobilize various organs of the body to feel and deeply understand the multimodal information resources related to English learning tasks.

\section{The Main Problems in Adult English Teaching under Epidemic Situation}

During the epidemic period, adult English learners' original online and offline hybrid learning mode was changed to online learning mode, which put forward higher requirements for adult English teaching. For adult learners, it is necessary not only to learn basic English knowledge during the epidemic period, but also to consciously adhere to learning English in future study and work, and constantly adapt to the requirements of society for interdisciplinary talents. For teachers, it is necessary not only to stimulate learners' interest in learning English during the epidemic period, but also to cultivate adult learners' ability and methods of autonomous learning English. The main problems of adult learners' English teaching under the epidemic situation include the following three aspects:

\subsection{The Information Ability of Adult Learners Is Not Strong}

Under the epidemic situation, adult learners' English learning should be mainly online autonomous learning. Because adult learners are deeply influenced by traditional teaching methods, their English learning still stays in face-to-face teaching, accustomed to teachers' systematic explanation of grammar and pronunciation, and they are not proficient in network information technology. Therefore, they have poor adaptability to distance English teaching and have certain exclusion psychology. They cannot skillfully use online teaching platform for autonomous learning.

Adult learners and English teachers are in a separated state during the epidemic period. The current teaching methods lack of effective interaction with learners, which is not conducive to the improvement of learners' learning enthusiasm, and is not conducive to the reform and innovation of teaching methods. In addition, some English teachers do not make full use of multimedia technology and online teaching platform, causing some teaching resources unused and wasted.

\subsection{The English Level of Adult Learners Is Not Sufficient}

Due to the lack of English learning environment, adult learners' English level gradually decreases as time goes on. Poor listening and speaking ability, small vocabulary and grammatical errors are the most common problems (Sun \& Sun, 2019). Compared with ordinary college learners, adult learners in the same class 
have different educational background and occupation status, and there are great differences in learning motivation, and these differences will lead to great differences in English learning methods. Some learners lack interest and motivation in English learning, and some are lack of concentration.

Adult English learners bear a variety of family and social roles and responsibilities. The contradiction between work and study brings about problems such as less study time, more randomness and easy distraction. During the epidemic period, due to the lack of good and strong learning atmosphere on campus, the consciousness, learning efficiency and learning achievements of adult English learners are naturally greatly reduced.

\subsection{The Evaluation System of Adult Learners Is Not Reasonable}

Under the epidemic situation, English teachers should make full use of online course teaching resources, rely on various online teaching platforms at all levels, and actively carry out online teaching activities such as online teaching and online learning. Accordingly, teaching evaluation should be changed. If the final examination is still regarded as the main standard to evaluate the teaching quality, many adult learners will only care about the final examination, and they will not be serious about the formative assessment focusing on process learning. This evaluation system will easily affect adult learners' initiative and interest in learning, which is not conducive to the improvement of learners' learning ability. In addition, there is no uniform standard for the arrangement of formative assessment. Some course assignments have a large number of questions and are difficult. Adult Learners often need to spend a lot of time to complete them, which leads to the learners' low learning enthusiasm.

\section{Exploration on Multimodal Teaching Mode for Adult English Learners under Epidemic Situation}

In view of the problems encountered in adult learners' English teaching under the epidemic situation, multimodal teaching mode can be adopted to fully stimulate adult learners' interest in English learning and achieve good English teaching effect. The reform of adult English teaching mode under the guidance of multimodal concept, uses online learning platform and mobile APP and other multimodal learning platforms to guide teaching, and carries out live broadcast teaching through cloud classroom and DingTalk, etc., and organizes teaching activities at three levels including teaching preparation, teaching organization and teaching evaluation, so as to cultivate adult English learners' autonomous learning ability.

\subsection{Teaching Preparation: Using Multimodal Learning Platform to Build Autonomous Learning Mode}

Under the multimodal teaching mode, the relationship between teachers and learners changes, and learners become the main body of learning. During the 
epidemic period, English teachers should make full use of the multimodal learning platform to let learners know the teaching objectives and contents. At the same time, they should integrate a large number of teaching resources and build a online autonomous learning mode suitable for adult English learners.

\subsubsection{Clarifying Teaching Objectives}

English teachers should clarify curriculum objectives and teaching objectives to learners. Clear curriculum objectives and teaching objectives can let learners know the knowledge points and skills to be mastered in each class, understand the key points and difficulties of each unit, and have clear objectives and directions for learning. According to the characteristics of adult learners, teachers should actively guide them to make their own English learning plans and arrange their study time reasonably. English teachers should upload guidance content on the online learning platform, including goal setting, micro-lectures self-study, pre class quiz, etc.

\subsubsection{Presenting Teaching Contents}

Teachers use information technology to divide English teaching content into teaching videos, which should be presented in the form of micro-lectures. Each class is composed of several micro-lectures. Learners can carry out on-demand broadcast according to their own level and actual needs, which is conducive to learners' personalized English learning (Zhu, 2016). Adult learners' English learning level is uneven. The length of pre class learning video should be strictly controlled, with 5 - 10 minutes as the appropriate. The teaching content is divided into several micro-lecture videos to reflect the interest. The most important thing is to make the micro-lectures from the perspective of learners, not from the perspective of teachers. It should reflect the student-oriented teaching idea, from easy to difficult, step by step, layer by layer, to stimulate learners' learning motivation and enthusiasm (Zhang, 2013).

\subsubsection{Integrating Teaching Resources}

Teachers should integrate the teaching resources of English curriculum, including both electronic teaching plan and teaching courseware, as well as other online course resources, such as literature and teaching cases, English exercises and English test papers, course questionnaire, English practice, teaching video, etc. English teachers should put the course guidance on the online learning platform in advance and urge the learners to study independently. At the same time, teachers should monitor the learning process of adult learners. Based on this, adult English learners can make use of the fragmented time after work to finish preview independently through online learning, so as to improve their independent thinking ability and inquiry ability.

\subsection{Teaching Organization: Implementing Multimodal Teaching Strategy to Provide Clear Learning Guidance}

Multimodal teaching strategies include role play, role conversion, classroom re- 
port, answering doubts, interactive inquiry, etc. Adult English teaching mode generally adopts the hybrid teaching mode of combination of online learning and offline learning. Under the epidemic situation, online learning is mainly used, and cloud classroom and DingTalk are used to carry out live broadcast teaching. Live broadcast teaching is an online course learning mode with the help of live online platform (Gan, 2017). The use of multimodal teaching theory has changed the allocation of class time, the input of discourse, the state of classroom behavior and the state of classroom participation between teachers and learners. Adult English learners have changed from passive learning to active learning.

\subsubsection{Online Autonomous Learning}

During the epidemic period, online autonomous learning adopts the teaching mode of online self-learning, and the teaching activities focus on individual autonomous learning of adult English learners. Teachers should stimulate learners' learning interest and motivation to the maximum extent. English teachers should give adult learners enough learning support, help them get familiar with the operation methods of online learning as soon as possible, make clear the learning objectives, arrange the study time reasonably, and study online on time, so as to give full play to learners' personality, and fully stimulate their enthusiasm and initiative.

\subsubsection{Live Broadcasting Teaching}

The combination of multimodal theory and English teaching makes the task of teachers and learners more clear. During the live broadcast teaching in the epidemic period, the allocation of time between English teachers and adult learners is more reasonable, teachers will not over output the language in class, and the learners will not be too tired (Lan, 2019). Teachers should try to figure out the personal characteristics of adult English learners, concentrate on teaching skills, and consciously design teaching scenes and rhythms, so as to mobilize learners' emotions and stimulate their interest in learning. Teachers should combine the teaching content with the English language, interpret new words and text. Through the multi-modal information input channels such as electronic teaching plan, teaching pictures, audio and video, a rich multi-modal English learning environment is set up for learners from the aspects of hearing, vision and touch. These environments not only improve the effect of learners' absorbing English language knowledge, but also are more beneficial to learners' English language output training. Through the multi-modal teaching strategies such as role conversion, role play and classroom report, supplemented by diversified homework arrangement, the advantages of adult learners' autonomous learning of different learning types can be reflected, and good English teaching effect can be achieved.

\subsubsection{Real Time Interaction}

In order to effectively implement the teaching process, we should make full use of the advantages of live broadcast and carry out real time interaction in class 
during the epidemic period. In the process of teaching, English teachers should reflect the teaching objectives and difficult points, carry out teaching activities step by step, give necessary guidance and explanation according to learners' answers and questions, create English learning situation, reasonably set up listening, speaking, reading and writing links, reflect the communicative and practical English learning, increase the sense of presence in English learning, and constantly stimulate learners' learning enthusiasm and internal motivation. In multimodal teaching mode, books are no longer the only source of knowledge, and teachers are no longer the only authoritative interpreter of language knowledge. Teachers guide learners by different means, effectively mobilize the enthusiasm of learners and improve their multiple listening, speaking, reading and writing abilities.

\subsection{Teaching Evaluation: Adopting Multimodal Teaching Evaluation to Execute Reasonable Teaching Assessment}

The teaching evaluation of adult learners' English learning should include formative assessment and summative evaluation (Wang, 2020). Teaching evaluation under the concept of multimodality is not a simple paper homework and final exam, but also includes learners' works exhibition, presentation performance, online learning track and so on.

\subsubsection{Formative Evaluation}

At present, the assessment index of formative assessment is not clear enough. Some teachers only take the completion of learners' homework as the basis of assessment. This relatively single evaluation method can not accurately and truly reflect the learners' learning situation. The formative evaluation under the multimodal concept should take the online learning platform as the carrier, including the indicators of learners' online learning trajectory, learners' works exhibition, report performance, etc., so as to comprehensively reflect the learners' learning situation. In addition, English teachers should pay attention to the monitoring and evaluation of learners' online learning process, including adult learners' attendance, watching videos, browsing resources, downloading resources, posting, replying times, and completing homework, and determine the proportion of their usual performance according to the weight, and formulate quantitative formative assessment indicators.

\subsubsection{Summative Evaluation}

Summative evaluation refers to learners' final examination results. Summative evaluation is an important part of the whole teaching evaluation. It can be used as a main basis for evaluating the effectiveness of teaching, but it must not be the only basis. English teachers should combine the summative evaluation and formative evaluation of adult learners' English learning to get an effective teaching evaluation. Teaching evaluation can not only guide and diagnose adult learners' English learning, but also provide reference for English teachers to improve 
English teaching methods and improve English teaching efficiency.

It can be seen that multimodal teaching, with the help of the complementary advantages of various modes, promotes the internalization and understanding of English knowledge for adult learners, highlights the characteristics and advantages of English teaching under the concept of multimodality, and is conducive to the optimization of English teaching.

\section{Conclusion}

There is a certain gap between adult learners and college learners in terms of age or English level. Under the epidemic situation, the advantages of multimodal teaching mode are more and more obvious compared with the traditional single teaching mode. Multimodal learning platforms, such as online learning platform and mobile APP, can mobilize various resources and systems to build a multimodal autonomous learning environment for adult English learners. It is not only conducive to the cultivation of adult learners' multimodal communicative competence, but also can implement multimodal teaching strategies such as role play, role conversion, and classroom report. In addition, the multimodal teaching evaluation can promote the construction and internalization of learners' knowledge, so as to cultivate their practical ability and innovative spirit. It is necessary to fully combine the characteristics of adult learners in learning English and establish their awareness of autonomous learning. Multimodal teaching mode is in line with the needs of adult English learners for teaching mode innovation under the epidemic situation, and also in line with the actual situation of adult English teaching.

\section{Acknowledgements}

My thanks to the anonymous reviewers for reading and commenting on the early drafts of this article.

\section{Funding}

The project is supported by Exploration and Practice of Multimodal Teaching Mode for Adult English Learners under Epidemic Situation (Grant No. 2020YQJY552), Special Subject of "Epidemic Situation and Education" of Zhejiang Provincial Education Science Regulated Research in 2020. Innovation Research Team of English Teaching Paradigm of Zhejiang Open University in 2019. Huang Ruihong Excellent Teacher Studio of Applied English.

\section{Conflicts of Interest}

The author declares no conflicts of interest regarding the publication of this paper.

\section{References}

Gan, Y. (2017). Research on Hybrid College English Teaching Based on Live Online 
Course. Education Academic Monthly, 11, 79-87.

Kress, G., \& Van Leeuwen, T. (2001). Multimodal Discourse: The Modes and Media of Contemporary Communication (pp. 21-22). London: Edward Arnold.

Lan, X. (2019). Reconstruction and Reflection of Distance English Teaching Ideas under Flipped Classroom Model. Journal of Yunnan Open University, 11, 22-28.

Sun, L. J., \& Sun, Y. (2019). Adult English Listening and Speaking Ability Training Based on Multimedia Distance Teaching Platform. China Adult Education, 3, 60-62.

Tan, S. E., Marissa, K. L., \& O’Hallonran, K. L. (2012). Multimodal Analysis Image (pp. 31-35). Singapore: Multimodal Analysis Company.

Wang, H. (2020). Research on ESP English Mixed Teaching Mode Based on Multimodal "Mobile" Environment. Journal Reading and Writing, 1, 2.

Zhang, D. L. (2009). Exploration of the Comprehensive Theoretical Framework of Multimodal Discourse Analysis. Chinese Foreign Languages, 1, 23-30.

https://doi.org/10.1007/978-3-8349-8397-8_3

Zhang, Y. C. (2013). Research and Thinking on Micro Lecture Construction. China Education Network, 10, 21-23.

Zhang, Y. Y. (2017). Reconstructing the English Teaching Concept under the Background of 'Internet Plus. English Teacher, 1, 25-27.

Zhu, J. X. (2016). Research on Multimodal Learning of Adult Foreign Trade English from the Perspective of Ubiquitous Learning. Education and Teaching Forum, 1, 195-196. 